\title{
THE CORRELATION OF CORPORATE CULTURE, INTERPERSONAL RELATION AND PERFORMANCE APPRAISAL SYSTEM TO OBJECTIVITY OF PERFORMANCE APPRAISAL IN COMPANY
}

\author{
Sumargo, Master of Management \\ Faculty of Economy, Airlangga University, Indonesia \\ E-mail: margomarsono@gmail.com
}

\begin{abstract}
The purposes of this study are: describing and analyzing the correlation of organizational culture, interpersonal relations, performance appraisal system to the objectivity of performance appraisal; arranging organization culture role model, interpersonal relation, the performance appraisal system towards improving the objectivity of performance appraisal. This study uses three questionnaires to find out information from the respondents, and based on multiple regression calculations with SPSS Windows Software. The results showed that organizational culture, interpersonal relationship and performance appraisal system significantly influence objectivity performance assessment in the company.
\end{abstract}

\section{KEY WORDS}

Organization culture, interpersonal relation, performance appraisal system, performance appraisal objectivity.

The success of an organization is determined by the leadership developed in that organization and the competence has given by its members/organization culture to achieve that goal. In line with the importance of human resources within the organization, human resource is the most important element determines the success or failure of an organization to conduct various activities and in the context of achieving the goals and objectives of the unit/organizations. Currently, many organizations need to change the culture of the agency to ensure its survival or to gain more competitive benefits. This is often driven by the fact that existing cultures are sometimes no longer able to improve the situation in the future as the organization needs it. The strengths of the organization's external environment can be as a signal the need for cultural change, for example, with increases of sharp competition in an agency's environment, then demanding a change of organizational culture to be able to respond faster what the society wants. The power of cultural change is not only coming from the external's environment but also can come from the inside of the environment / internal. For instance, if the head office implements the new approaches to the organizational management to create a good performance (Verbeeten, 2008).

In practice, the organizational culture refers to the values and beliefs associated with the operational systems undertaken by an organization. Organizational culture is important to provide consistency and flexibility in order to be responsive to customer demand, and to achieve a sustainable competitive advantage, learning culture is found to be a very important organizational capability (Ahmad, 2012).

Company $X$ is a State Owned Enterprise engaged in the business of seaport services. A brief history of Company $X$ at the beginning of its establishment is a State Company, whose establishment set under the Government Regulation no. 19 the year 1960. In the period of 1969 until 1983 form State Company has been changed to the name of Port Agency of Enterprises based on Government Regulation No. 1 the year 1969. Further, in the period of 1983 until 1992 changed to Public Company in Port based on The Government Regulation No. 16 the year 1983 and The Government Regulation No. 6 the year 1985. Therefore, since 1992 along with the rapid development of business, the status of Perum changes to the Persero/State Owned Company.

Company $X$ has a headquarter that located in Surabaya, which manages for 40 ports that are grouped into 19 branches and 21 sub-branches spread across 7 Provinces, that is at 
East Java, Central Java, South Kalimantan, Central Kalimantan, Bali, West Nusa Tenggara and East Nusa Tenggara. The Act number 17 the year 2008 concerning shipping, has changed the policy of business in the seaport sector that regulates the separation of regulatory functions mandated to the Port Authority as a representative of the government and for the port operators itself mandated to Port Business Entity. According to the new regulation, either local government and private entity have the same right to become a Port Business Entity or terminal operator, they are able to build a port and operate the port business with the condition they have a license as a Port Business Entity and also owned the port facilities required especially berth facility (terminal).

With regard to the new regulation, the port business competition will be more stringent. Company $X$ will have new competitors' presence that can be a threat or the challenges. This is forced Company $X$ to always improving their quality of services and have the same working standards, including in all the branches of Company $X$. Therefore, in order to prepare the organization in the competing era which goes more and more tightening, Company $X$ is required to improve their performance to win the competition. One of the supporting factors is Human Resources (HR) which is a factor that determined the success of the company. Appropriate and competitive of the Human Resource Management and Performance is an intellectual property (Intellectual Asset) owned by the company that will be able to bring the company to successfully achieve their vision and mission.

To enable assessing the performance of existing human resources, Company $X$ has an HR performance assessment system named SMKI (Individual Performance Management System). The SMKI is a system built to manage the individual employee performance that includes the activities of planning, monitoring, appraisal and rewards activities of the employee performance achievements. The SMKI is made and implementing has a purpose to assist the leader/organization cultures enable to manage their staff performance, therefore the leader able to increase the opportunity to achieve the goals of organization cultures individuals, work units and companies. The purpose of the creation of the SMKI is to improve a performance's organization through the correlation organization culture of the target work unit into an individual performance goal. Therefore, implementing the SMKI has the goal to monitor all the individual performance and the result of a performance appraisal can as a reference in promoting employees. In addition, that is, as one of the considerations of employee's promotion and a reference in the award of year-end organization cultures.

The SMKI shows bend from the expectation during its implementation. The implementation of the SMKI has not been working objectively. This is known from the interview with one of the Managers in the branch office. When the Manager was asked to recommend the staff to be promoted, they did not use the SMKI as a basis for promotion because the Manager did not feel the SMKI as a valid reference information for promotion. The Manager was argued that the SMKI is not filled based on actual conditions, but because of the sense of discomfort. This sense of discomfort is due to the results of the SMKI as one of the bases for the calculation of year-end bonus and the leader will feel sorry if there are any staff who do not receive as much as what other colleagues in a unit get. In addition, the SMKI is not based on the job description of each staff, therefore the results of the SMKI assessment cannot show the result of the performance due to it is not based on employee job description, but only based on the organization cultures' estimation.

The result of the interview with The Human Resources division at Company $X$ reveals that the current use of the SMKI is different from the original goals. Based on the interview revealed that there are certain of the work unit has requested the HR department to fill in the SMKI of their unit with the argument that SMKI is an HR's responsibility. In another case found there are any superiors who asked their staff to fill in his SMKI form, then it sent back to sign by the leader for the purpose to make it like assessed made by the leader.

The career competition in Company $X$ is very open, therefore it allows younger employees to be ahead of senior employees in terms of career. This open competition condition allows friction between employees. However, the Indonesian culture is often someone to feel bad then eventually make the competition like does not exist. Even though, a competition sometimes creates an interpersonal conflict that occurs between employees. 
The Implementation of SMKI is not like what initially expected by Company X. This condition raises the two assumptions that whether the corporate culture gives a person influence in performing a performance evaluation and whether interpersonal conflict makes someone afraid to perform performance appraisal.

The purposes of this study are 1. To describe and analyze the correlation of organizational culture, interpersonal relationships, performance appraisal system with the objectivity of performance appraisal. 2. To establish the role model of organizational culture, interpersonal relationships, performance appraisal systems towards improving the objectivity of performance appraisal.

\section{LITERATURE REVIEW}

The theory that supports performance is the goal setting theory, where Sekaran (1992) explains about one type of organizational development intervention is setting. The implementation process of this setting is an approach to understanding management based on goals or outcomes that help to provide an understanding of management or management aspects, outcomes, and objectives.

The purpose of a performance appraisal is to provide personal and periodic employee feedback, control employee work behavior, establish or compensate, predict career advancement within the company, measure employee and company training needs, counsel, set and measure objectives, facilitate policy setting within reduction of employees (Obong, 2009).

The use of objectivity performance appraisal, among others, is to make better decisions, higher employee satisfaction and motivation, a stronger commitment to the company, so that the company can be more effective. Employees will receive an assessment if they are allowed to participate, discuss plans and objectives, and are assessed on the basis of factors relevant to their work. Effective assessment has five criteria: validity that can be seen from assessment factors, reliability or consistency of judgment, discriminatory or distinguishes the results of judgment, free of bias, and relevant or appropriate to the situation and performance conditions (Ochoti, 2012).

The corporate culture in this study uses measurements based on the characteristics of organizational culture (O'Reilly, Chatman, and Caldwell, 1991). The observable organizational culture is behavioral patterns that are manifestations or expressions of basic assumptions and values. O'Reilly, Chatman, and Caldwell (1991, in Munandar, 2001) suggested the following organizational cultural traits:

1. Innovation and risk taking

Seeking new opportunities, taking risks, experimenting, and not being hampered by formal policies and practices.

2. Stability and security

Appreciate the foreseeable things, security, and use of rules that exert behavior.

3. Appreciation to people

Showing tolerance, fairness, and respect for others.

4. Orientation of results

Having high attention and expectation of results, achievements, and actions.

5. Team orientation and collaboration

Work together in a coordinated and collaborative way.

6. Aggressiveness and competition

Take decisive actions in markets in the face of competitors.

Cross-cultural research on society conducted by Smith and Bond, (1995) proves that the cultural background also affects one's interpersonal relationships. Through this research, it is known that people with eastern culture are more cooperative, willing to help foreigners in their environment. More open and more empathetic, so that interpersonal relationship built can be done well and satisfactorily. While western societies that tend to be more closed will be more difficult in establishing good interpersonal relationships. 


\section{METHODS OF RESEARCH}

The type of research used is explanatory research, this research emphasizes on the relationship between research variables by testing the description hypothesis contains description but the focus lies in the relationship between variables (Singarimbun, 1989).

The population in this study is all human resources working in Company $X$ a number of 1879 employees. Sampling technique in this research use purposive sampling with criteria:

1. Employee with minimum working experience of 10 Years

2. Employees who have the authority to assess

Pursuant to purposive sampling obtained sample of 132 respondents.

Primary data required in this study are data related to organizational culture, interpersonal relationships, performance appraisal systems and performance appraisal objectivity.

The secondary data used in this study is data on literature and information that support such data employee Company $X$.

This study uses three questionnaires to find out information from respondents. The three questionnaires are the corporate culture questionnaire, the objectivity assessment questionnaire of the SMKI instrument, and the interpersonal relationship questionnaire.

Each questionnaire has a favorable and unfavorable item. Item Favorable is the item that supports the measured variable and the unfavorable item is an item that does not support the measured variable. Each answer has four alternative answers SS (Strongly Agree), S (Agree), (TS) Disagree, STS (Strongly Disagree) Assessment for each item ranges from 1-4, for favorites responses SS gets value 4, S obtains value 3 , TS gets 2 , STS gets 1 . Conversely, for unfavorable item STS answers get value 4 and subsequently in sequence. If the subject gives a sign to the STS column then it can be interpreted that the subject strongly disagrees with the statement relating to aspects of the questionnaire, but vice versa if the subject ticks on the SS column then it can be interpreted the subject agrees with the statement relating to the questionnaire aspect.

In this study there are four variables, namely organizational culture, interpersonal relationships, performance appraisal system and objectivity of performance appraisal defined as follows:

a. Interpersonal relationships are interactions between a person with others in work situations and in the organization as a motivation to work together productively to achieve economic, psychological and social satisfaction.

b. Organizational culture is the basic assumptions and beliefs that exist among members of the organization. Based on the explanation of the experts can be taken the conclusion of corporate culture is the values developed and believed by all members of the company.

c. The performance appraisal system, which results from the performance appraisal that has expected/expected value, has an effective valuation instrument and an effective appraisal valence.

d. The objectivity of performance appraisal is a more detailed assessment of work to make it easier for those authorized to assess in providing objective judgments and recommendations.

Validity test in this research using KMO (Gujarati, 1999).

Reliability testing of all items/questions used in this study will use the formula Cronbach alpha (coefficient alpha Cronbach), which in general is considered reliable if the value of alpha Cronbach> 0.6 (Gujarati, 1999).

In this study statistical calculation using Moderating Regression Analysis Model (MRA) with the following equation:

$$
Y=\beta o+\beta 1 X 1+\beta 2 X 2+\beta 3 X 3+e
$$


Where: $\beta 0=$ Intercept; $\beta 1, \beta 2, \beta 3=$ The coefficient of independent variable parameters; $\mathrm{e}=$ error sampling; $\mathrm{X} 3=$ Performance appraisal system; $\mathrm{Y}=$ Objectivity of performance appraisal; $\mathrm{X} 1=$ Organizational culture; $\mathrm{X} 2=$ Interpersonal relationship.

On the basis of the following stages:

1. Normality Test

Normality test in this study also seen from ratio Kolmogorov Smirnov (KS), if KS ratio above 0.05 then data is normally distributed (Gujarati, 1999).

2. Heteroscedasticity Test

This study also conducted a gleyser test, significance value> 0.05 then no Heteroscedasticity or in other words there is no influence of independent variables on alpha Cronbach (Gujarati, 1999).

3. Multicollinearity test

The multicollinearity test can be performed by way of regressing the analysis model and performing the correlation test between the independent variables using VIF. The VIF limit is 10 if the VIF value is greater than 10 then there is multicollinearity (Gujarati, 1999).

4. Autocorrelation Test

This test uses Durbin Watson's Test to see whether there is an autocorrelation (Gujarati, 1999).

5. Statistical Test $t$

The t-test is a test of hypothesis used to answer the problem in this research partially (individually).

If the level of significance is greater than 0.05 or $5 \%$ then the hypothesis proposed is rejected or said to be insignificant, meaning partially independent variable $(X)$ has no significant effect on the dependent variable $(\mathrm{Y})=$ hypothesis rejected.

The hypothesis is formulated as follows: $\mathrm{H} 1: \mathrm{bi} \neq 0$

This means that there is a significant influence of the independent variable $\mathrm{Xi}$ against the dependent variable $(\mathrm{Y})$.

The t-count value can be found by the formula: (Gujarati, 1999): If $t$-count $>t$-table ( $\alpha, n-$ $\mathrm{k}-\mathrm{I})$, then $\mathrm{HO}$ is rejected; and If $\mathrm{t}$-count $<\mathrm{t}$-table $(\alpha, \mathrm{n}-\mathrm{k}-\mathrm{I})$, then $\mathrm{HO}$ is accepted.

6. Statistical Test $F$

The statistical test $\mathrm{F}$ basically indicates whether all independent or independent variables included in the model have a mutual influence on the dependent/bound variable. If the significance level is less than 0.05 or $5 \%$, it means together all the independent variables $(X)$ have a significant effect on the dependent variable $(Y)$. And if the level of significance is greater than 0.05 or $5 \%$, it means together all the independent variables $(X)$ has no significant effect on the dependent variable $(\mathrm{Y})$.

Hypothesis $0 \mathrm{Ho}$ to be tested is whether all parameters in the model are equal to zero, or: Ho: $\mathrm{b} 1=\mathrm{b} 2=$ $=\mathrm{bk}=0$

That is, whether all independent variables are not a significant explanation of the dependent variable. The alternative hypothesis $(\mathrm{HA})$ is not all parameters simultaneously equal to zero, or: HA: b1 \# b2 \# \# bk \# 0

That is, all independent variables are simultaneously a significant explanation of the dependent variable.

7. Coefficient of Determination (R2)

The coefficient of Determination (R2) essentially measures how far the model's ability to explain the variation of the dependent variable. The coefficient of determination is between zero and one. The small value of R2 means the ability of the independent variables to explain the variation of the dependent variable is very limited. A value close to one means the independent variables provide almost all the information needed to predict the variation of the dependent variable (Gujarati, 1995).

\section{RESULTS AND DISCUSSION}

In this research, respondents used as samples are human resources of Company $\mathrm{X}$. The method of data collection used is a questionnaire to obtain employee perceptions data 
on organizational culture and interpersonal relations, while the performance appraisal system was obtained by using SMKI data on the objectivity of performance appraisal. Total of 132 employees of Company $X$ was given the questionnaires.

Organization Culture Variable:

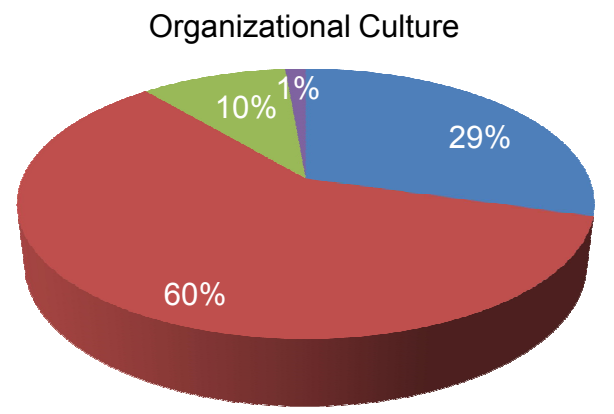

Figure 1 - Answer Results Distribution of Organizational Variables Respondents (Source: Processed primer data, 2017)

Distribution of respondents' answer result for organization culture variable shows that the 'strongly agree' answers (score 4) are 29\%, the 'agree' answers (score 3 ) are $60 \%$, the 'disagree'answers (score 2) are 10\%, and the 'strongly disagree'answers (score 1) are 1\%. Interpersonal Relation Variable:

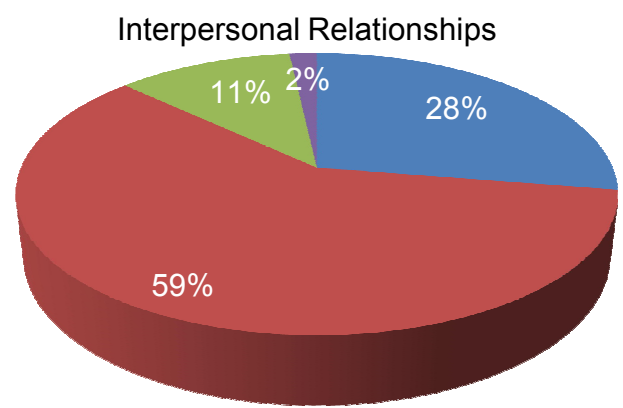

Figure 2 - Answer Results Distribution of Interpersonal Relation Variables Respondents (Source: Processed primary data, 2017)

Distribution of respondents' answer result for interpersonal relations variables shows that the 'strongly agree' answers (score 4) are 28\%, the 'agree' answers (score 3 ) are 59\%, the 'disagree' answers (score 2 ) are 11\%, and the 'strongly disagree' answers (score 1) are $2 \%$.

Objectivity of Performance Appraisal Variables:

Objectivity Performance Assessment

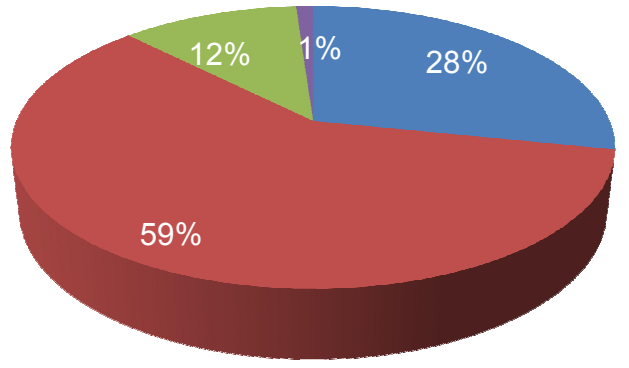

Figure 3 - Answer Results Distribution of Objectivity of Performance Appraisal Variables Respondents (Source: Processed primary data, 2017) 
Distribution of respondents' answer result for objectivity of performance appraisal variables shows that the 'strongly agree' answers (score 4) are $28 \%$, the 'agree' answers (score 3) are 59\%, the 'disagree' answers (score 2) are 12\%, and the 'strongly disagree' answers (score 1 ) are $1 \%$.

Data Analysis:

Validity Test. Validity test that used in this research, which determines the item whether is valid or not, is by looking at the direction of its correlation and the ratio of the $r$ value to the $r$ table. In $r$ table of $5 \%$ error, level $r$ table is 0.171 ( $\mathrm{df}=132-2=130$, according to $r$ table data presented in attachment). Since all items have a positive correlation and the $r$ value is bigger than the $r$ table $(0.171)$, it can be stated that all items in this research variable are declared valid.

Reliability Test:

Table 1 - Instrument Reliability Test Results

\begin{tabular}{lll}
\hline Variabel & Reliability Coefficient & Status \\
\hline Organizational culture & 0.935 & Reliabel \\
Interpersonal Relationships & 0.847 & Reliabel \\
Objectivity Performance Assessment & 0.857 & Reliabel \\
\hline
\end{tabular}

Source: Processed primary data, 2017

The table above shows that coefficient resulted from reliability test in organization culture variable is 0.935 , the interpersonal relation is 0.847 , and performance appraisal objectivity is 0.857 . Thus, the reliability test results produce alpha Cronbach value $>0.6$, it means that the test is reliable. Therefore, the three measurement instruments of the variables studied can be stated as reliable so it can be used as data for further analysis.

Classical Assumption Test:

1. Normality Test. The data of normality test was generated using Kolmogorov Smirnov test, with the following results:

Table 3 - The Result of Normality Test

One-Sample Kolmogorov-Smirnov Test

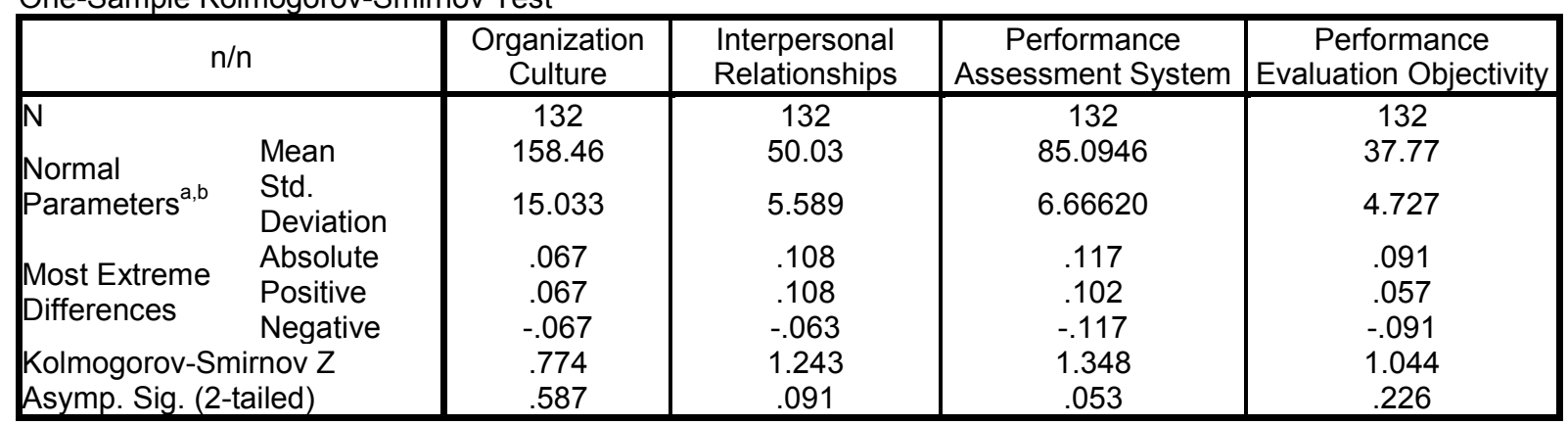

a. Test distribution is Normal.

b. Calculated from data.

Source: Processed primary data, 2017.

2. Heteroscedasticity Test. The heteroscedasticity test was performed by looking at the presence of a particular pattern on the scatter plot chart between SRESID and ZPRED where the $Y$ axis is $Y$ that has been predicted and the $X$ axis is the residual with results presented in Figure 4.

The graphs on the test results show that the residuals do not form a clear pattern, and the spots are spread above and below the zeros on the $Y$ axis. Thus, the residual value of the model is not influenced by the dependent or independent variable so that there is no heteroscedasticity problem in the model proposed.

3. Multicolinearity Test. The table 4 shows that all variables used as predictors of the regression model show a tolerance value of $<0,10$, where everything is below 10 and the 
Variance Inflation Factor (VIF) value of all variables is above 0.10 . It means that the free variable used in the study does not indicate the existence of a multicolinearity phenomenon which means that all variables can be used as independent variables.

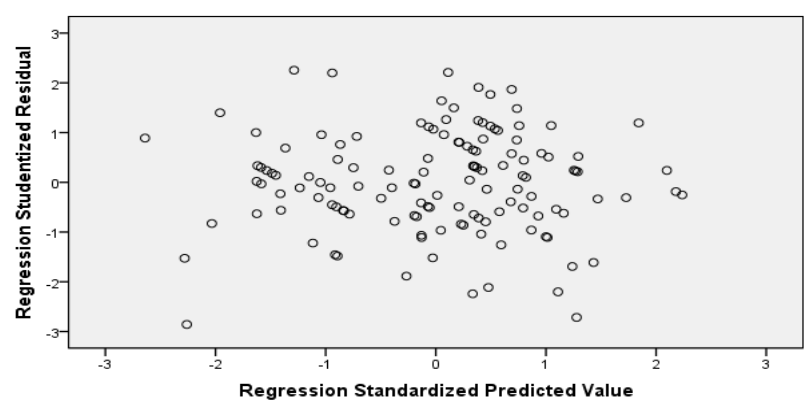

Figure 4 - The Result of Heteroscedasticity Test (Source: Processed primary data, 2017)

Table 4 - The Result of Multicolinearity Test

Coefficients $^{\mathrm{a}}$

\begin{tabular}{lcc}
\hline & \multirow{2}{*}{ Model } & \multicolumn{2}{c}{ Collinearity Statistics } \\
\cline { 2 - 3 } & Tolerance & VIF \\
\hline Organizational culture & 0.493 & 2.030 \\
Interpersonal Relationships & 0.489 & 2.047 \\
Performance Appraisal System & 0.954 & 1.048 \\
\hline
\end{tabular}

a. Dependent Variable: Objectivity Performance Assessment

Source: Processed primary data, 2017.

4. Autocorrelation Test. Autocorrelation test in this study was conducted by looking at Durbin Watson correlation coefficient to determine whether there is autocorrelation can be done by using Durbin-Watson (DW test) statistic with the following results:

Table 5 - The Result of Autocorrelation Test

Model Summary ${ }^{\mathrm{b}}$

\begin{tabular}{|c|c|c|c|c|c|}
\hline Model & $\mathrm{R}$ & R Square & Adjusted R Square & Std. Error of the Estimate & Durbin-Watson \\
\hline 1 & $.757^{\mathrm{a}}$ & .573 & .563 & 3.124 & 1.344 \\
\hline
\end{tabular}

a. Predictors: (Constant), Performance Appraisal System, Organizational Culture, Interpersonal Relations

b. Dependent Variable: Objectivity Performance Assessment

Source: Processed primary data, 2017.

Based on the table above, it can be seen that Durbin Watson value is 1.334 . Then, this value was compared with table significance value of 0.05 with the number of sample $\mathrm{N}=132$ and number of variable $4(\mathrm{~K}=4)$, and the obtained value of Durbin Watson table are $\mathrm{dL}$ 1.621 and dU 1.762. Durbin Watson value (4-dW) $4-1.344=2.656$ is greater than the upper limit (dU) of 1.344 so it can be concluded that there is no autocorrelation.

Table 6 - Regression of the Influence of Organizational Culture, Interpersonal Relations, and Performance Appraisal System towards the Objectivity of Performance Appraisal

\begin{tabular}{|c|c|c|c|c|c|}
\hline \multirow{2}{*}{ Model } & \multicolumn{2}{|c|}{ Unstandardized Coefficients } & Standardized Coefficients & \multirow{2}{*}{$\mathrm{t}$} & \multirow{2}{*}{ Sig. } \\
\hline & $\mathrm{B}$ & Std. Error & Beta & & \\
\hline (Constant) & -15.792 & 4.172 & & -3.785 & .000 \\
\hline Organizational culture & .123 & .026 & .393 & 4.774 & .000 \\
\hline Interpersonal Relationships & .149 & .070 & .176 & 2.129 & .035 \\
\hline Performance Appraisal System & .312 & .042 & .440 & 7.444 & .000 \\
\hline
\end{tabular}

a. Dependent Variable: Objectivity Performance Assessment

Source: Processed primary data, 2017. 

follow:

The regression equation that can be formed from the table acorporate cultureve as

$$
Y=-.15 .792+0.123 . X 1+0.149 . X 2+0.312 . X 3
$$

The explanations of interpretation of formed regression equation are as follows:

- Constant obtained is -15.792 . It means that by using a regression equation if the objectivity of performance appraisal is not influenced by organizational culture, interpersonal relation, and performance appraisal system, then the objectivity of performance appraisal will be equal to -15.792 .

- The regression coefficient of organizational culture variable is 0.123 . It means that any improvement of organizational culture will improve the objectivity of performance appraisal by 0.123 .

- Regression coefficient of interpersonal relation variable is 0.149 . It means that any improvement of interpersonal relations will improve the objectivity of performance appraisal by 0.149 .

- The regression coefficient of performance appraisal system variables is 0.312 . It means that any performance appraisal conducted will improve the objectivity of performance appraisal by 0.312 .

Statistic Test with T-Test

T-test conducted in this study aims to test the significance influence of an independent variable individually to the variation of the dependent variables, and also to test the separate study hypothesis. If the calculated $t$ is $>t$-table and significance level is $<(0.05)$, then the independent variable individually affects the dependent variable with the result of the analysis as follows:

Table 7 - The Result of T-test

Coefficients $^{\mathrm{a}}$

\begin{tabular}{|l|c|c|c|c|c|}
\hline \multirow{2}{*}{ Model } & \multicolumn{2}{|c|}{ Unstandardized Coefficients } & Standardized Coefficients & \multirow{2}{*}{$\mathrm{t}$} & Sig. \\
\cline { 2 - 5 } & $\mathrm{B}$ & Std. Error & Beta & -3.785 & .000 \\
\hline (Constant) & -15.792 & 4.172 & .393 & 4.774 & .000 \\
Organizational culture & .123 & .026 & .176 & 2.129 & .035 \\
Interpersonal Relationships & .149 & .070 & .440 & 7.444 & .000 \\
\hline Performance Appraisal System & .312 & .042 & & 7.40 \\
\hline
\end{tabular}

a. Dependent Variable: Objectivity Performance Assessment

Source: Processed primary data, 2017.

\section{DISCUSSION OF RESULTS}

The Effect of Organizational Culture towards Objectivity of Performance appraisal in $P T$. Company $X$. The result of hypothesis testing with T-test shows that the value of T-count is 4.774 and T-table is 1.656 , with sig value equal to 0.000 . Since T-count $(4,774)>$ T-table (1.656), then $\mathrm{Ho}$ is rejected and $\mathrm{Ha}$ is accepted. Thus, it can be stated that the hypothesis based on T-test for organizational culture variables significantly influence the objectivity of performance appraisal in Company $\mathrm{X}$.

The results show that organizational culture affects the objectivity of performance appraisal in Company X. The results of this study are also in accordance with Robbins's statement which stated that organizational culture is a shared perception shared by members of the organization so that it becomes a culture that will lead the organization towards a better development. Accordingly, Yilmaz and Ergun also stated that organizational culture is the basic assumption and belief that exists between members of the organization. The results of this study are also in line with the results of the data frequency distribution questionnaire for organizational culture variables in which the highest response $(60 \%)$ supports the proposed statement related to these variables. 
The Influence Interpersonal Relation towards Objectivity Performance Appraisal in Company $X$. The hypothesis testing with T-test shows that T-count is 2.129 and T-table is 1.656, with the sig value of 0.035 . Since the T-count (2.129) > T-table (1.656), then Ho is rejected and $\mathrm{Ha}$ is accepted. Therefore, it is assumed that hypothesis based on the T-test for interpersonal relations variable significantly influence the performance appraisal objectivity in Company $\mathrm{X}$.

The result of this study shows that interpersonal relation affects the objectivity of performance appraisal in Company X. This result obtained is consistent with those as stated by Stoetzer who defined the interpersonal relations as a firm relationship between two or more individuals. Likewise, Dachner pointed out that to create, develop, and maintain a certain relationship, there are four domain skills that individuals should have which are; trust and willingness to get to know each other, good communication, able to take and give support, able to solve the problem properly, including emotion coping. This result is also in line with the results of the data frequency distribution questionnaire of interpersonal relations variable, where the highest response (59\%) supports proposed statements related to those variables.

The Influence of Performance Appraisal System toward Objectivity of Performance Appraisal in Company $X$. The result of hypothesis testing with T-test shows that the T-count is 7.444 and T-table is 1.656 , with the sig value of 0.000 . Since the T-count (7444) $>$ T-table (1656), so $\mathrm{Ho}$ is rejected and $\mathrm{Ha}$ is accepted. Therefore, it is stated that hypothesis regarding T-test of performance appraisal system variable significantly influences the objectivity of performance appraisal in Company X.

The result of this research shows that the performance appraisal system significantly influences the objectivity of performance appraisal in Company $X$. These results are in accordance with Cavalluzzo and Ittner who stated that appraisal system is an output result of performance appraisal which has an expectancy-value, an effective appraisal instrument, and an effective assessor valence. Following this result, Robbins stated that there are three criteria for doing the performance appraisal, which is (a) individual tasks; (b) individual attitudes; (c) individual characteristics.

The Influence of Organizational Culture, Interpersonal Relation, and Performance Appraisal System to Objectivity of Performance appraisal in Company $X$. The result of simultaneous test proved that there is a positive and significant relationship between organizational culture, interpersonal relation, and performance appraisal system to the objectivity of performance appraisal. The result obtained from F-test resulting F-count of 57.352 with the significance level of 0.000 . Due to sig $<0.05$, the regression model can be used to predict the objectivity of performance appraisal. Since the hypothesis of the sig value $<0.05$, so $\mathrm{Ho}$ is rejected and $\mathrm{Ha}$ is accepted, which means that the hypothesis which stated that organizational culture, interpersonal relation, as well as performance appraisal system, significantly influence the objectivity of performance appraisal in Company $\mathbf{X}$ is true.

Moreover, the results of this research are in line with the result of data distribution frequency of questionnaire answers for performance appraisal objectivity variable, where the highest answer (59\%) supports the proposed statements of those variables.

In addition to the explanation above, it can be concluded that the theory of organizational culture, interpersonal relation, and performance appraisal system toward objectivity of performance appraisal is proved and can be explained to increase the objectivity of performance appraisal in Company $X$. Therefore, according to the hypothesis test with F-test in this research, organizational culture, interpersonal relationship, and performance appraisal system are all important variables which influence the objectivity of performance appraisal in Company $\mathrm{X}$.

\section{CONCLUSION}

Hypothesis Conclusion. Based on multiple regression calculations with Windows SPSS Software, the hypothesis conclusion is as follows: 
The higher the Organization Culture, the higher the objectivity performance appraisal, meaning the objectivity performance appraisal is built on organizational culture indicators.

The higher the Interpersonal Relation, the higher the objectivity performance appraisal, meaning the objectivity of performance appraisal is built by indicators of interpersonal relationships.

The higher the Performance Appraisal System, the higher the objectivity performance appraisal, meaning the objectivity of performance appraisal is built by Performance Appraisal System indicators.

Theoretical Implications. The theoretical implications of this study can be suggested through the following points:

- Organization culture has a positive influence on performance appraisal objectivity, this supports previous research conducted by farashahi et al., (2005). ahmad, (2012).

- Interpersonal Relation has a positive effect on performance appraisal objectivity performance, this supports the previous research conducted by stoetzer, (2010)

- Performance appraisal system has a positive effect on performance appraisal objectivity, this supports previous research conducted by ochoti et al., (2012).

Managerial Implications. The policy implications of this study can be suggested through the following points:

Company $X$ needs to improve the organizational culture through employee's selfdevelopment, employees who have run their responsibilities by completing the job quickly and on time need to be given self-development, it is expected that employees feel more appreciated, and fulfilled the need for his own development.

Company $X$ needs to improve the performance appraisal system by providing the widest opportunity for employees to develop their skills and knowledge by providing regular training opportunities, providing opportunities to continue the educational level either with corporate scholarships or own expenses as well as promotional opportunities for them who has potential.

Company $\mathrm{X}$ needs to improve Interpersonal Relation by providing equal rewards for employees by providing salary and incentive according to the achievement of targets, of leave incentive and life/health insurance and held a family gathering once a year to improve relationships among family employees.

Limitations of Research. Some research limitations that can be drawn from this research are as follows:

- The limitations of this research model due to a limitation of the low variable which explaining performance appraisal objectivity at Company $X$ needs, which is indicated by the value of the coefficient of determination is relatively small.

- During the process of distributing questionnaires, there are only 49 respondents returned, therefore need redistribution to meet the 132 respondents.

Future Research Agenda. The results of this study and the limitations found in the research can be a source of ideas for the development of this research in the future, the extent of the research suggested from this study are:

- Adding independent variables that affect the performance appraisal objectivity. The suggested variables are self-efficacy, this is because in providing services to the public is necessary to have a high confidence of the employees to increase the trust of service of Company $\mathrm{X}$, with high self-efficacy employees are able to solve the problem well.

- During the process of distributing questionnaires, it should be done by meeting them directly one by one so that the respondents understand the questionnaire's questions that already given.

\section{REFERENCES}

1. Ahmad, M. Shakil, (2012), "Impact of organizational culture on performance management practices in Pakistan" Business Intelligence Journal. 
2. Cavalluzzo, K.S. (2004). "Implementing performance measurement innovations: evidence from government."Accounting, Organizations and Society, 29, 243-67.

3. Farashahi, M., Hafso, T. and Molz, R. (2005), "Institutionalized norms of conducting research and social realities: a research synthesis of empirical works from 1983 to 2002", International Journal of Management Review, Vol. 7 No. 1, pp. 1-24

4. Gujarati, Damodar, (1999), Basic econometrika, PT. Gramedia

5. Kandula, S. R. (2006). Performance Management, New Delhi: Prentice Hall of India private limited.

6. Magee, K. C. (2002). "The impact of organizational culture on the implementation of performance management (Doctoral dissertation)." Available from Dissertations and Theses database (UMI No. 3047909).

7. Obong'o, S. O. (2009). "Implementation of performance contracting in Kenya" International Public Management Review, 10 (2), 66-84.

8. Robbins. Stephen. (1996), Manajemen sumber daya manusia, Pretice Hall.

9. Verbeeten, F. H. M. (2008), "Performance management practices in public sector organizations: Impact on performance."Accounting, Auditing \& Accountability Journal, 21(3), 427-454.

10. Walsh, K. \& Fisher, D. (2005)."Action inquiry and performance appraisals: Tools for organizational learning and development." Journal of the Learning Organization, 12 (1), 26-41.

11. Yilmaz, C. \& Ergun, E. (2008)."Organizational culture and firm effectiveness: An examination of relative effects of culture traits and the balanced culture hypothesis in an emerging economy." Journal of World Business, 43, 290-306. 